American Journal of Applied Sciences 6 (6): 1043-1046, 2009

ISSN 1546-9239

(C) 2009 Science Publications

\title{
Effect of Different Ages of a Rehabilitated Forest on Selected Physico-chemical Properties
}

\author{
Rajeswari A.P. Murugayah, Seca Gandaseca, \\ Osumanu Haruna Ahmed and Nik Muhamad Ab. Majid \\ Department of Crop Science, Faculty of Agriculture and Food Science, \\ University Putra Malaysia, Bintulu Campus, Sarawak, 97008 Bintulu, Sarawak, Malaysia
}

\begin{abstract}
Problem statement: This research was important because of still lack of information about rehabilitated tropical forest age effect on infiltration rate. The objectives of this study were to determine the influence of age of forest on soil water infiltration rate and to evaluate the influence of forest age on the relationship between water infiltration rate, soil organic matter and soil texture. Approach: This study was conducted under a rehabilitated forest at Bukit Nyabau (University Putra Malaysia Bintulu Campus, UPMKB) Forest. Soil organic matter, soil texture and infiltration rate were investigated in randomly selected blocks representing different age classes, namely two, four, six, eight and ten years. Results: The results indicated that 2, 4,6 and 8 year old forest were not significantly different in organic matter content with the mean of $8.10+2.75,9.32+3.50,9.55+1.71$ and $8.10+2.75 \%$ respectively. Besides, 10 year forest showed no significant differences compared with two and eight year forests. Soil texture for all the forests was sandy loam, except for the 4 year old forest which was a sandy clay loam. The lowest value of sand content was observed in four year forest. However, the clay content in this forest was statistically the highest compared with 2, 4, 8 and 10 year old forest. The infiltration rate of 6 years old forest was significantly greater in soil water infiltration rate with the mean of $5.0 \pm 0.02 \mathrm{~mm} \mathrm{~m}^{-1}$, compared with $2,4,8$ and 10 years old forest with the means of $2.6 \pm 0.02$, $4.2 \pm 0.03,3.6 \pm 0.03$ and $3.5 \pm 0.03 \mathrm{~mm} \mathrm{~m}^{-1}$ respectively. Eight and 10 year old forests showed no significant differences in terms of soil water infiltration rate and the lowest value of water infiltration rate was observed in the two year old forest. Conclusion: From the results, it can be concluded that the soil water infiltration rate in the forest is mainly influenced by soil texture and organic matter content, but not by forest age. However, the effect of soil texture was significant compared to organic matter which facilitates water movement into soil. Soil texture with higher percentage of sand and lower percentage of clay had higher infiltration rate.
\end{abstract}

Key words: Iinfiltration rate, soil texture, organic matter, forest age, rehabilitated forest

\section{INTRODUCTION}

In Sarawak, forest rehabilitation aims to restore the environmental protection functions of deforested areas, economic returns from the planting is not a major consideration. In this state, forest planting focuses on areas within the permanent forest estate which had been deforested by shifting cultivators $^{[1]}$. Forest rehabilitation can provide a range of economic, social and environmental benefits.

The water infiltration rate into soil matrix influences the amount of water storage in soil, which is available for plants, amount of runoff and erosion. Therefore, knowledge of water infiltration into soil is very important for soil and water conservation as well as minimizing the risk of non point source pollution. The process of infiltration strongly affects the redistribution of sediment, plant litter and seeds, vertically into the soil profile and laterally across the landscape ${ }^{[2]}$. The rate of water entry (infiltration rate) decreases overtime until it reaches a steady state or constant rate $^{[3]}$. Low infiltration rate is a major cause of water runoff and erosion ${ }^{[4]}$. In forest environments, various surface conditions can exist and it is important to characterize these conditions and their effect on infiltration ${ }^{[5]}$.

There are many researches about soil infiltration rate, but information on the effect of forest plantation age on infiltration rate is still rare. Therefore, the objectives of this study were: (i) To determine the 
effect of forest plantation age on soil infiltration rate, (ii) To evaluate the influence of forest age on the relationship between water infiltration rate, soil organic matter and soil texture.

\section{MATERIALS AND METHODS}

Study site: A study on infiltration rate of soil under rehabilitated forest with different plantation ages was conducted at JISE-UPM-UNIMAS rehabilitated forest at University Putra Malaysia, Bintulu, Sarawak. This is a joint research project on Rehabilitation of Tropical Rainforest Ecosystem by three parties, University Putra Malaysia (UPM), University Malaysia Sarawak (UNIMAS) and Japanese Center for International Studies in Ecology (JISE). It is located about $600 \mathrm{~km}$ northeast of Kuching, latitude $03^{\circ} 12^{\prime} \mathrm{N}$, longitude $113^{\circ} 02^{\prime} \mathrm{E}$ and $50 \mathrm{~m}$ above sea level. The soil of the study area belongs to Nyalau and Bekenu series, which are well drained. The JISE-UOM-UNIMASS rehabilitated forest is divided into for phases. All the studies were carried out at phase four with 2, 4, 6, 8 and 10 years old plantation ages.

\section{Data collection:}

Soil sampling: The equipment used in soil sampling were auger, plastic bags, measuring tape and compass. A $25 \times 25 \mathrm{~m}$ area of the 2 year old rehabilitated forest was demarcated. Two depths (0-15 and 15-30 cm) of 10 soil samples were taken randomly using auger. The soil was placed into plastic bags and labeled. The plastic bags with soil samples were transported to laboratory for analysis. The aforementioned procedure was repeated for $4,6,8$ and 10 years old rehabilitated forest.

Infiltration rate: Apparatuses used to analyze soil infiltration rate were double ring infiltrometer, hammer, plastic sheet, water and stopwatch. The procedure was as follows: Both rings of the infiltrometer were driven into soil to $8-10 \mathrm{~cm}$. A plastic sheet was placed in the inner ring. The buffer area was filled with water to $10 \mathrm{~cm}$ and the water level was maintained. Immediately, water was introduced into the inner ring with plastic sheet until it reached $2 \mathrm{~cm}$. The plastic sheet was removed and a stop watch was started. For the first 15 minutes, the level of the water was recorded for every 1 minute, followed by every $5 \mathrm{~min}$. until the water level became constant.

\section{Laboratory analysis:}

Drying, crushing and sieving soil sample: All the soil samples were air dried for few days. The air dried soils were crushed manually and sieved to pass a $2 \mathrm{~mm}$ sieve. The sieved soil samples were transferred into plastic bags and labeled.

Organic matter analysis: Apparatus used in determining soil organic matter were crucible, furnace and weighing balance. Five crucibles were weighed and labeled as R1, R2, R3, R4 and R5. Ten grams of soil sample were weighed into each crucible. The crucibles were placed into a furnace set at $300^{\circ} \mathrm{C}$ for $1 \mathrm{~h}$, after which, the temperature was increased to $750^{\circ} \mathrm{C}$. After 4-5 h, the furnace was switched off. The percentage of organic matter in the soil was determined.

Soil texture analysis: The texture of the study area was determined by the hydrometer method ${ }^{[6]}$. Devices used in this determination were, measuring cylinder $(1000 \mathrm{~mL})$, bicars, soil stirrer, hydrometer, 4M of $\mathrm{NaOH}$ solution, stirring rod, weighing balance and thermometer. Twenty grams of each 10 soil samples (0$15 \mathrm{~cm}$ depth) for one plot were placed in a bicar. The soil samples were mixed well. A $50 \mathrm{~g}$ of soil sample from the mixer was placed in a blender cup of the soil stirrer. The blender cup with the soil sample was filled with distilled water. A $10 \mathrm{~mL}$ of $\mathrm{NaOH} 4 \mathrm{M}$ solution was added drop wise to the blender cup. The soil was stirred for $15 \mathrm{~min}$. After $15 \mathrm{~min}$., the soil suspension was transferred into a $1000 \mathrm{~mL}$ measuring cylinder. The remaining soil residue was washed transferred into the cylinder by spraying with distilled water. Distilled water was added to the cylinder until the volume reached $1130 \mathrm{~mL}$. The suspension in the cylinder was stirred with a stirring rod. A hydrometer was placed into the suspension exactly 40s after the stirring was stopped. The reading of the hydrometer was recorded. The hydrometer was removed and rinsed. The temperature of the suspension was recorded. Steps 1114 were repeated for the second reading. The measuring cylinder was left undisturbed for $2 \mathrm{~h}$. Hydrometer and temperature readings of the suspension were taken again for the third time. The soil texture was determined using soil texture software.

Soil moisture content determination: A clean flask was weighed. Ten grams of soil sample were placed into the flask. The flask was closed with a ground stopper lid and carefully weighed. The lid of the flask was removed. The flask with soil was placed in a oven and left to dry between 105 and $110^{\circ} \mathrm{C}$ for $24 \mathrm{~h}$. After $24 \mathrm{~h}$, the flask was allowed to cool in a desicator. The lid was placed back on the flask and weighed. 
Data analysis: The obtained results were analyzed using SAS version 9.1. Significant difference among the samples was tested by using one-way ANOVA and Duncan Multiple Range Test.

\section{RESULTS}

Organic matter: The results in Table 1 show that 2, 4 , 6 and 8 years old forests were not significantly different in organic matter. Ten year old forest also showed no significant difference compared with two and eight years old forests.

Infiltration rate: The infiltration rate of 6 year old forest was significantly greater compared with $2,4,8$ and 10 years old forests. Eight and 10 years old forests showed no significant difference in terms of soil water infiltration rate (Table 1).

Soil texture: Table 2 shows sand, clay and silt contents of the soil at different ages forest. The soil texture of all of the forests were sandy loam, except for 4 year old forest which was sandy clay loam. The sand of 2, 6 and 10 years old forests were not significantly different. The clay contents of 2, 6 and 8 years old forests were not significantly different. Ten year old forest showed statistically lowest value of clay. In the case of silt content, 4, 8 and 10 years old forests were not significantly different but statistically higher compared with 6 and 2 years old forests.

Table 1: Organic matter, soil texture and soil infiltration rate at different ages of forests

\begin{tabular}{llll}
\hline Age & Organic matter $(\%)$ & Texture & $\begin{array}{l}\text { Infiltration } \\
\text { Rate }\left(\mathrm{mm} \mathrm{m}^{-1}\right)\end{array}$ \\
\hline 2 & $8.10^{\mathrm{ab}} \pm 2.75$ & Sandy loam & $2.6^{\mathrm{d}} \pm 0.02$ \\
4 & $9.32^{\mathrm{a}} \pm 3.50$ & Sandy clay loam & $4.2^{\mathrm{b}} \pm 0.03$ \\
6 & $9.55^{\mathrm{a}} \pm 1.71$ & Sandy loam & $5.0^{\mathrm{a}} \pm 0.02$ \\
8 & $8.10^{\mathrm{ab}} \pm 2.75$ & Sandy loam & $5.0^{\mathrm{a}} \pm 0.02$ \\
10 & $6.82^{\mathrm{b}} \pm 0.71$ & Sandy loam & $3.5^{\mathrm{c}} \pm 0.03$ \\
\hline
\end{tabular}

Within column having the same alphabets are not significantly different at $\mathrm{p}=0.05$ using DNMRT

Table 2: Sand, clay and silt contents of soil at different ages of forests

\begin{tabular}{lllll}
\hline Age & Sand (\%) & Clay $(\%)$ & Silt $(\%)$ & Texture \\
\hline 2 & $62.0^{\mathrm{ab}} \pm 1.73$ & $17.6^{\mathrm{b}} \pm 0.01$ & $20.4^{\mathrm{b}} \pm 1.73$ & Sandy loam \\
4 & $51.8^{\mathrm{c}} \pm 1.00$ & $21.2^{\mathrm{a}} \pm 2.00$ & $27.0^{\mathrm{a}} \pm 1.00$ & Sandy clay loam \\
6 & $64.7^{\mathrm{a}} \pm 2.31$ & $14.8^{\mathrm{c}} \pm 1.39$ & $20.5^{\mathrm{b}} \pm 0.92$ & Sandy loam \\
8 & $59.3^{\mathrm{b}} \pm 0.64$ & $16.0^{\mathrm{bc}} \pm 0.35$ & $24.7^{\mathrm{a}} \pm 0.29$ & Sandy loam \\
10 & $64.7^{\mathrm{a}} \pm 1.15$ & $10.0^{\mathrm{d}} \pm 0.01$ & $25.3^{\mathrm{a}} \pm 1.19$ & Sandy loam \\
\hline
\end{tabular}

Within columns having the same alphabets are not significantly different at $p=0.05$ using the DNMRT

\section{DISCUSSION}

Water infiltration of soil highly depends on the pores present in the soil. Naturally, forest soils have a high percentage of macro-pores through which large quantities of water can move into the soil. Most of the macro-pores in the forest are developed from old root channels or from burros and tunnels made by insects, worms and other animals. Some macro-pores result from structural pores and cracks in the soil. The volume of these pores and their continuity determines the flow of water into the soil. Soil organic matter and soil texture are two important factors to determine soil water infiltration rate.

Soil organic matter consists of all types of carbon containing substances in the soil, except carbonates. It is a mixture of plant and animal residues in the various stages of decomposition, the bodies of living and dead microorganisms and substances synthesized from breakdown products of the above ${ }^{[7]}$. Soil organic matter helps to improve soil aggregate which allows rapid water movement into the soil. The age of the trees are always correlated with litter production. Forest litter layers physically protects the soil surface from extreme temperature and moisture content, offer mechanical protection from raindrop impact and erosion forces and improve water infiltration rates. Depending on the species, the older trees produce more litters to contribute to the organic matter building up. Through decomposition process, the consequences of litter quality and quantity influences organic matter building up in the soil ${ }^{[8]}$. The soil with higher organic matter content will have a higher infiltration rate ${ }^{[9]}$. In this study, organic matter content in 10 year old forest was the lowest compared with four and six years probably because of the higher decomposition rate of the litters. High litter fall rate followed by lower of decomposition rates usually results in high litter accumulation and high soil organic matter ${ }^{[10]}$. Therefore, it can be concluded that the ten years old forest produces high rates of litter fall and high rate of decomposition compared with other forests, thus, it has lowest value of organic matter content. The present of soil microorganism and earthworms helps the plant litters to decompose fast ${ }^{[11]}$. From this statement, it can be said that there are higher amount of soil microorganism and earthworms in ten year forest, thus the decomposition rate in this forest is very high to produce low organic matter content.

Water flows rapidly through sandy soils and slowly through clay soils (Singer). Sandy soils mainly have large pores, compared to clay soils. This is 
supported by the results obtained in Table 1 and 2, the 6 year old forest which were high in organic matter content and sand content had the highest value of water infiltration rate. Although the organic matter content in the 4 year old forest was not significantly different compared to 6 year old forest, the infiltration rate in this forest was lower due to its higher clay content and lower sand content.

In this study, the total water infiltration in all of the forests increased until they reached a steady state. This was because, when water is supplied to an initially dry soil, the suction gradients across the soil surface become very high, which results in a high infiltration rate. As the wetting front moves downward, the suction gradient across soil profile decreases, which limits the rate of water infiltration into the soil surface. After a long time, the infiltration rate approaches zero. The decrease in infiltration rate may also be caused by dispersion of aggregates or slaking, soil compaction and surface sealing or clogging of the soil pores ${ }^{[12]}$. Pores in the soil are clogged when the soil pores are saturated with water.

Pores in forest soil are always related with the trees in that particular forest. Depending on the age of the tree, the tree roots create pores and enlarge the existing pores while they grow. The standing trees in 10 year old forest are bigger compared to the rest. They should have larger roots to create pores and enlarge the existing pores to allow rapid water movement. The infiltration rate in 8 and 10 years old forests were lower compared to 4 and 6 years probably because of the living roots of these forest trees blocked the existing pores in the soil, making them ineffective for water transport. In this case, the pores cannot transmit the water into the soil. As a result, the water infiltration rate becomes lower.

\section{CONCLUSION}

In this study, soil water infiltration rate is influenced by soil texture and organic matter content, but not forest ages. However, the effect of soil texture is higher compared to organic matter to allow rapid water movement into soil. Soil texture with higher percentage of sand has higher infiltration rate.

\section{REFERENCES}

1. Barnes, B.V., D.R. Zak, S.R. Denton and S.H. Spurr, 1988. Forest Ecology. 4th Edn., John Wiley and sons, Inc, USA., ISBN: 0471047325, pp: 700 .
2. Burton, L.D., 2000. Introduction to Forestry Science. 2nd Edn., Delmar Publishers, USA., ISBN: 1418030872, pp: 130-141.

3. Lal, R. and M.K. Shukla, 2004. Priciples of Soil Physics. 1st Edn., Marcel Dekker, Inc., New York, USA., ISBN: 0824753240, pp: 528.

4. Christopher, T.B.S. and Jamal, 2006. Soil Physical Analyses. Vol. 1. University Putra Malaysia Press, Serdang, ISBN: 9833455646, pp: 18-21.

5. Coleman, D.C., J.M. Oades and G. Uehara, 1989. Dynamics of Soil Organic Matter in Tropical Ecosystem. University Hawaii, Niftal Project, ISBN: 10: 0824812514 , pp: 352.

6. Jones, J.B., 2001. Laboratory Guide for Conducting Soil Tests and Plant Analysis. 1st Edn., CRC Press, USA., ISBN: 0849302064, pp: 384.

7. Filip, J., 1994. Soil Conservation and Silviculture. In: Soil Conservation, Dvorak, J. and L. Navak (Eds.). Elsevier, Czech Republic, ISBN: 0444987924, pp: 399.

8. Hemmat, A., I. Ahmadi and A. Masoumi, 2007. Water infiltration and clod size distribution as influenced by ploughshare type, soil water content and ploughing depth. J. Biosci. Eng., 97: 257-256. http://cat.inist.fr/?aModele $=$ afficheN\&cpsidt $=1887$ 0238

9. Lado, M., A. Paz and M. Ben-Hur, 2004. Organic matter and aggregate size interactions in infiltration, seal formation and soil loss. J. Soil Sci. Soc. Am., 68: 935-942. http://cat.inist.fr/?aModele $=$ afficheN\&cpsidt $=1573$ 1762

10. Vogt, K.A., C.C. Grier and D.J. Vogh, 1986. Production, turnover and nutrient dynamics of above and belowground detritus of world forests. J. Adv. Ecol. Res., 15: 303-377.

11. White, R.E., 1997. Principles and Practice of Soil Science: The Soils as a Natural Resources. 4th Edn., Blackwell Science, United Kingdom, ISBN: 9780632064557, pp: 34-58.

12. Iistedt, U., A. Malmer, E. Verbeeten and D. Murdiyarso, 2007. The effect of afforestation on water infiltration in the tropics: A systematic review and meta-analysis. J. For. Ecol. Manage., 251: 45-51.

http://www.cifor.cgiar.org/Publications/Detail?pid $=2337$ 